Article

\title{
Facile Synthesis of a Series of Non-Symmetric Thioethers Including a Benzothiazole Moiety and Their Use as Efficient In Vitro anti-Trypanosoma cruzi Agents
}

\author{
Alcives Avila-Sorrosa 1,*D, Jazz D. Tapia-Alvarado ${ }^{1}$, Benjamín Nogueda-Torres ${ }^{2}$, \\ Karla Fabiola Chacón-Vargas ${ }^{2}$, Francisco Díaz-Cedillo ${ }^{1}$, María Elena Vargas-Díaz ${ }^{1}$ and \\ David Morales-Morales ${ }^{3, *(D)}$ \\ 1 Instituto Politécnico Nacional, Escuela Nacional de Ciencias Biológicas, Departamento de Química Orgánica, \\ Carpio y Plan de Ayala S/N, Colonia Santo Tomás, 11340 Ciudad de México, México \\ 2 Instituto Politécnico Nacional, Escuela Nacional de Ciencias Biológicas, Departamento de Parasitología, \\ Carpio y Plan de Ayala S/N, Colonia Santo Tomás, 11340 Ciudad de México, México \\ 3 Instituto de Química, Universidad Nacional Autónoma de México, Circuito Exterior s/n, Ciudad \\ Universitaria, C.P. 04510, Ciudad de México, México \\ * Correspondence: aavilas@ipn.mx (A.A.-S.); damor@unam.mx (D.M.-M.); Tel.: +52-555-729-6000 (A.A.-S.); \\ +52-55-56224514 (D.M.-M.)
}

Received: 24 July 2019; Accepted: 19 August 2019; Published: 24 August 2019

check for updates

\begin{abstract}
A series of 2-benzylsulfanyl benzothiazole (BTA) derivatives were synthesized and fully characterized and in vitro tested against two strains of T. cruzi (NINOA and INC-5), exhibiting good activities at low concentrations.
\end{abstract}

Keywords: Trypanosoma cruzi; Chagas disease; benzothiazole derivatives; non-symmetric thioethers; neglected diseases

\section{Introduction}

The benzothiazole (BTA) is a heterocyclic compound of great interest in different areas of chemistry, materials, and biological sciences. The BTA core is rarely found in nature (e.g., luciferin, marine natural compounds, etc.); thus, most of the known derivatives have been prepared by chemical synthesis. Nevertheless, compounds including these structures have found applications in the synthesis of polymers, dyes, chemical sensors, herbicides, etc. In addition, they represent a wide variety of important biologically active xenobiotics, including antidiabetic [1], anticonvulsant agent [2], anticancer [3], anti-inflammatory [4], and antiparasitic [5]. Thus, this privileged pharmacological unit is one of the "master keys" for the design and synthesis of bioactive compounds with applications in medicinal chemistry and pharmaceuticals.

Several reports have shown that functionalization of the BTA system on position 2 is key for their enhanced biological activity mainly as antimicrobial agents. Thus, there is currently a growing interest in obtaining 2-substituted BTAs to direct them as significant active antiparasitic agents [6-10].

In this line, American trypanosomiasis or Chagas disease is caused by the hemoflagellate protozoan Trypanosoma cruzi (T. cruzi) that is transmitted by vectors, mainly triatomine insects [11]. This parasitic infection is considered neglected and affects mainly countries of tropical zones of Americas, where it is estimated that between 6 to 7 million people are infected with T. cruzi [12], and approximately 100 million people are at risk of infection with this protozoan [13]. Due to the increased number of cases of infections registered in recent decades in non-endemic areas, such as the United States, Canada, and European countries [14], Chagas disease is a serious emerging public health problem worldwide. 
Clinically, Chagas disease occurs in acute and chronic phases. The first can be asymptomatic or manifest with fever or edema, or both, on the face and extremities. This phase is characterized by the presence of many parasites in the trypomastigote stadium circulating through the bloodstream, while in the chronic phase, there is a lower blood parasitaemia, but manifestations of the disease are most serious, leading to heart problems, megaviscera, neurological changes, and sudden death [15].

Regarding treatment, there are only two nitrated chemotherapeutic agents: nifurtimox (Nfx) ((R,S)-3-methyl-N-[(1E)-(5-nitro-2-furyl)methylene]thiomorpholin-4-amine-1,1-dioxide) and benznidazole (Bnz) (N-benzyl-2-(2-nitro-1H-imidazol-1-yl)acetamide) (Figure 1), which are usually more effective in the acute stage. However, therapy with both drugs shows serious side effects, as well as the development of resistance to parasites [16].<smiles>CC1CS(=O)(=O)CCN1/N=C/c1ccc([N+](=O)[O-])o1</smiles>

Nifurtimox $(N f x)$<smiles>O=C(Cn1ccnc1[N+](=O)[O-])NCc1ccccc1</smiles>

Benznidazole (Bnz)

Figure 1. Main antichagasic chemotherapeutic agents.

Thus, based on the above, we would like to report the facile synthesis of a series of non-symmetric thioethers, including a BTA moiety, and their use as efficient in vitro anti-Trypanosoma cruzi agents.

\section{Results and Discussion}

\subsection{Synthesis}

The structures of the series of BTA derivatives obtained are shown in Table 1. Their synthesis was achieved in a facile, single step procedure from the stoichiometric reaction of 2-mercaptoBTA 1 with different benzyl chlorides $(\mathbf{2} \mathbf{a}-\mathbf{g})$, according to Scheme 1 . Affording derivatives $\mathbf{3 a}-\mathbf{g}$ (yields ranging from 75 to $87 \%$ ) as microcrystalline solids (derivatives $\mathbf{5}$ and $\mathbf{6}$ were obtained as liquids) with melting points lower than $100{ }^{\circ} \mathrm{C}$ (Table 1$)$.

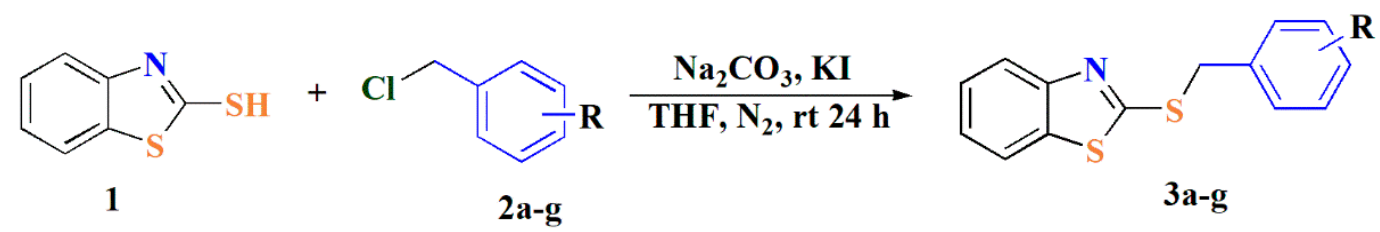

Scheme 1. Synthesis of 2-benzylsulfanyl-BTA derivatives.

Analysis of compounds 2-(benzylthio)benzo[d]thiazole (3a) [17], 2-(4-chlorobenzylthio)benzo[d]thiazole (3b) [18], 2-(4-methoxybenzylthio)benzo[d]thiazole (3c) [19], 2-(4-fluorobenzylthio)benzo[d]thiazole (3d) [17], and 2-(3-fluorobenzylthio)benzo[d]thiazole (3e) [20] are coherent with those reported in the literature. 
Table 1. Structures and yields of synthesized BTA derivatives.

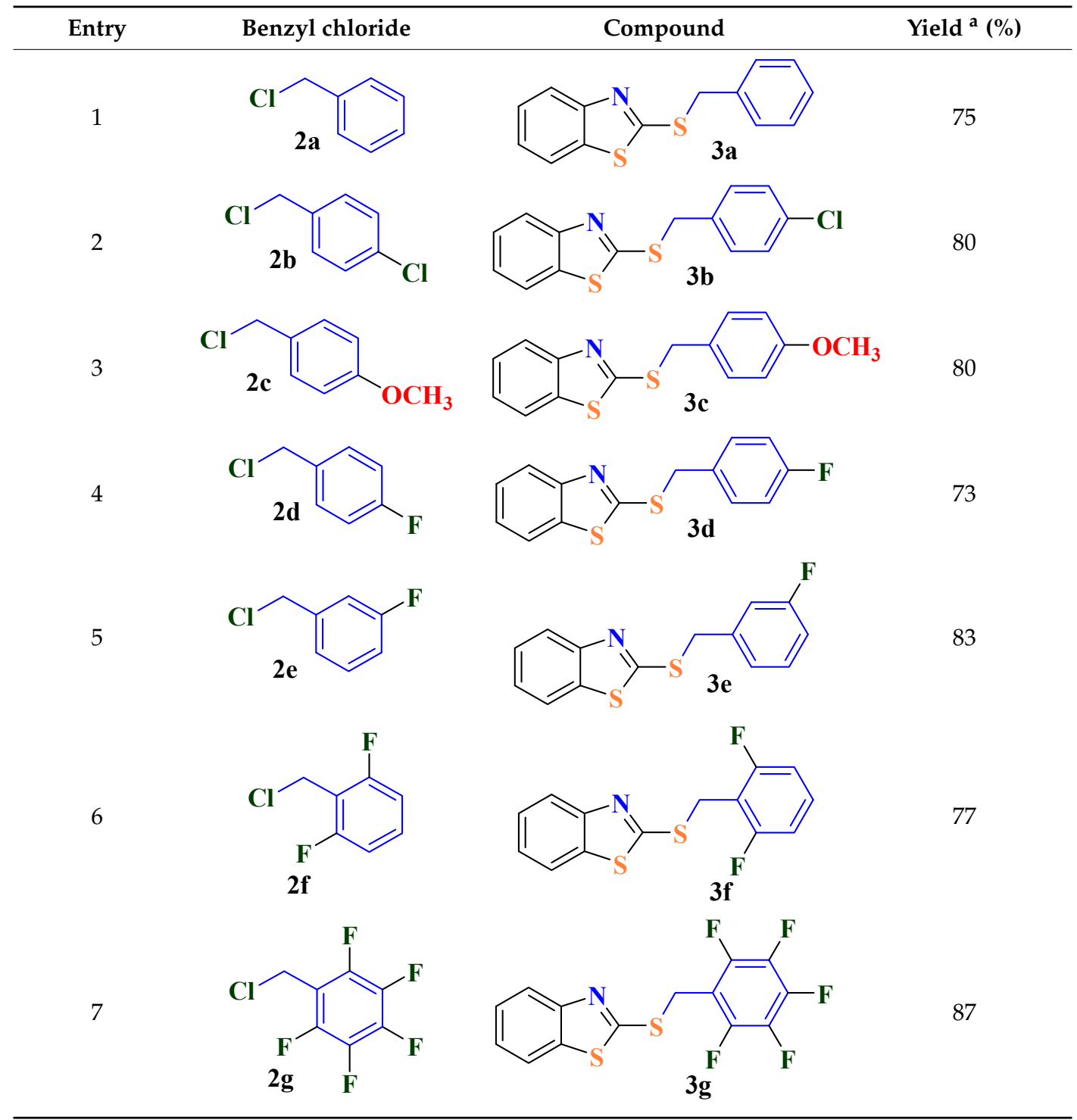

a Isolated yield based on 2-mercaptoBTA.

Spectroscopic Characterization

The series of compounds were characterized by spectroscopic methods (IR, NMR), mass spectrometry (EM-ESI), and elemental analysis. In general, the IR vibration analysis shows the main diagnostic signals for the different BTA derivatives. Hence, C-H stretching bands are observed in the range of $v 3080$ to $2840 \mathrm{~cm}^{-1}$ due to the aromatic and aliphatic hydrocarbon units. Between $v$ 1610 and $1360 \mathrm{~cm}^{-1}$, a series of sharp and intense bands due to the vibrations of the BTA moiety are observed. In the case of the fluorinated compounds, a very intense signal around $v 990 \mathrm{~cm}^{-1}$ due to the C-F stretch is observed. Mass spectrometry analysis by electrospray ionization showed, in all cases, a single peak in the corresponding spectra due to the molecular ion plus one mass unit $\left(\mathrm{M}^{+}+1\right)$.

Further, analysis by ${ }^{1} \mathrm{H},{ }^{13} \mathrm{C}\left\{{ }^{1} \mathrm{H}\right\}$, and ${ }^{19} \mathrm{~F}\left\{{ }^{1} \mathrm{H}\right\}$ NMR afforded spectra exhibiting a number of signals on the proper chemical shifts coherent with the proposed structures of the series of BTAs. Thus, ${ }^{1} \mathrm{H}$ NMR spectra showed signals in the range of 7.84-7.30 ppm due to the protons of the BTA moiety $(4 \mathrm{H})$. In addition, a diagnostic signal due to the benzylic protons $(2 \mathrm{H})$ was found at about $5 \mathrm{ppm}$. Moreover, the spectra of the BTA derivatives having a para-substituted benzene ring, exhibited a typical set of signals corresponding to an $\mathrm{AA}^{\prime} \mathrm{BB}^{\prime}$ system $(4 \mathrm{H})$ in the aromatic zone between 7.9 and $6.7 \mathrm{ppm}$. 
Besides, the ${ }^{13} \mathrm{C}\left\{{ }^{1} \mathrm{H}\right\}$ NMR spectra exhibited the seven expected signals for the BTA fragment in the range of 135-110 ppm. The signal due to the benzylic carbon was observed between $24-36 \mathrm{ppm}$. In the case of the fluorine-bonded carbons, these exhibited coupling constants of $J=244 \mathrm{~Hz}$, this value being characteristic for this type of couplings. Finally, the ${ }^{19} \mathrm{~F}\left\{{ }^{1} \mathrm{H}\right\}$ NMR spectra obtained were consistent with the different fluorine substituted derivatives $\mathbf{3} \mathbf{d}-\mathbf{g}$.

\subsection{Biological Evaluation}

As mentioned above, the acute phase of American trypanosomiasis is characterized by a high parasitaemia and bloodstream presence trypomastigotes, these parasitic forms are highly infectious for myocardial cells and enterocytes among others, where they can remain for years as intracellular amastigotes resulting in the chronic phase of the disease [21]. Thus, given the fact that parasites on the bloodstream trypomastigotes stadium are the infective form, in mammals it becomes important the performing of trypanocidal evaluation of new compounds considering at least two or more strains endemic in the region.

In this line, the trypanocidal activity of the series of 2-benzylsulfanyl-BTA derivatives was evaluated in vitro against bloodstream trypomastigotes of two strains of T. cruzi endemic in Mexico (Table 2). Hence, different concentrations were evaluated to determine the $\mathrm{LC}_{50}$ of each compound. Additionally, the cytotoxic effect and the selectivity index (SI) were determined. Table 2 shows the results obtained for each of the compounds, as well as the reference drugs employed.

Table 2. Biological activity of BTA derivatives on T. cruzi NINOA and INC-5 strain.

\begin{tabular}{|c|c|c|c|c|c|}
\hline \multirow{2}{*}{ Compound } & \multicolumn{2}{|c|}{$\begin{array}{l}\text { Bloodstream Trypomastigotes } \\
\text { LC }_{50}(\mu \mathrm{M})\end{array}$} & \multirow{2}{*}{$\begin{array}{c}\text { Macrophages } \\
\text { J774A.1 } \\
\text { CC }_{50}(\mu \mathrm{M})\end{array}$} & \multicolumn{2}{|c|}{$\begin{array}{c}\mathrm{SI} \\
\left(\mathrm{CC}_{50} / \mathrm{LC}_{50}\right)\end{array}$} \\
\hline & $\begin{array}{l}\text { T. cruzi } \\
\text { NINOA }\end{array}$ & $\begin{array}{l}\text { T. cruzi } \\
\text { INC-5 }\end{array}$ & & $\begin{array}{l}\text { T. cruzi } \\
\text { NINOA }\end{array}$ & $\begin{array}{l}\text { T. cruzi } \\
\text { INC-5 }\end{array}$ \\
\hline $3 a$ & $123.44 \pm 21.86$ & $335.59 \pm 35.7$ & $>900$ & $>7.29$ & $>2.68$ \\
\hline $3 b$ & $>350$ & $262.62 \pm 12.33$ & $>900$ & $\mathrm{Nd}$ & $>3.42$ \\
\hline $3 c$ & $307.82 \pm 28.88$ & $275.67 \pm 22.96$ & $>900$ & $>2.92$ & $>3.26$ \\
\hline $3 d$ & $>350$ & $>350$ & $869.91 \pm 26.8$ & $\mathrm{Nd}$ & $\mathrm{Nd}$ \\
\hline $3 e$ & $>350$ & $>350$ & $784.82 \pm 25.45$ & $\mathrm{Nd}$ & $\mathrm{Nd}$ \\
\hline $3 f$ & $109.76 \pm 23.18$ & $259.81 \pm 25.56$ & $491.88 \pm 10.09$ & 4.48 & 1.91 \\
\hline $3 g$ & $146.95 \pm 21.01$ & $185.35 \pm 12.95$ & $249.56 \pm 9.44$ & 1.69 & 1.34 \\
\hline$N f x$ & $96.26 \pm 11.48$ & $127.63 \pm 14.97$ & $347.32 \pm 18.26$ & 3.61 & 2.72 \\
\hline$B n z$ & $173.46 \pm 15.89$ & $216.57 \pm 23.08$ & $223.43 \pm 11.23$ & 1.28 & 1.05 \\
\hline \multicolumn{6}{|c|}{ Nd: Not determined. } \\
\hline
\end{tabular}

From Table 2, it can be observed that compounds 3a, 3f, and $\mathbf{3 g}$ exhibited trypanocidal activity in bloodstream trypomastigotes of T. cruzi NINOA, with lower values of $\mathrm{LC}_{50}$ than $\mathrm{Bnz}\left(\mathrm{LC}_{50}=173.46 \mu \mathrm{M}\right)$, and having compound $3 \mathrm{f}$ as the best of this group $\left(\mathrm{LC}_{50}=109.76 \mu \mathrm{M}\right)$ exhibiting similar activity to that of Nfx $\left(\mathrm{LC}_{50}=96.96 \mu \mathrm{M}\right)$. However, when the evaluation was performed on trypomastigotes of T. cruzi INC-5, compound $\mathbf{3 g}\left(\mathrm{LC}_{50}=185.35 \mu \mathrm{M}\right)$ exhibited the best trypanocidal effect when compared with Bnz $\left(\mathrm{LC}_{50}=216.57 \mu \mathrm{M}\right)$. In addition, compounds $3 \mathbf{b}\left(\mathrm{LC}_{50}=262.62 \mu \mathrm{M}\right), 3 \mathrm{c}\left(\mathrm{LC}_{50}=275.67 \mu \mathrm{M}\right)$ and $3 f\left(\mathrm{LC}_{50}=259.81 \mu \mathrm{M}\right)$ exhibited similar activities, however, still better that those observed with both reference drugs, being only closer to that produced by Bnz. Finally, compound $\mathbf{3 b}$ only showed activity against T. cruzi INC-5, while compounds $\mathbf{3 d}$ and $3 \mathbf{e}$ showed null activity in neither of both strains. None of the synthesized compounds exceeded the activity of Nfx in both strains.

Interestingly, when the cytotoxic effect in macrophages was studied, six of the seven BTA derivatives evaluated exhibited a reduced cytotoxic effect on mammalian cells, compared with both 
reference drugs. Hence, compounds $\mathbf{3 a}, \mathbf{3 b}, \mathbf{3} \mathbf{c}, \mathbf{3} \mathbf{d}$, and $\mathbf{3 e}$ were over two times less toxic than Nfx and about three-fold less toxic than Bnz. Compounds $\mathbf{3 d}$ and $\mathbf{3 e}$ were not considered in this analysis because they did not exhibit trypanocidal activity. Moreover, although compound $3 \mathrm{~g}$ resulted to be the most toxic compound of the series, it is still slightly less toxic than Bnz.

As a consequence of the combination of trypanocidal effect and low toxicity observed with compounds $\mathbf{3 a}, \mathbf{3 b}, \mathbf{3} \mathbf{c}$, and $\mathbf{3 f}$, their SI were better. Thus, all active compounds exhibited better SI values than Bnz in both strains. In the case of $\mathrm{Nfx}$, its SI value was surpassed by the values exhibited by compounds $3 \mathbf{a}$ and $\mathbf{3} \mathbf{f}$ on $T$. cruzi NINOA and by compounds $\mathbf{3} \mathbf{a}$ and $\mathbf{3} \mathbf{c}$ on T. cruzi INC-5. However, although compound $\mathbf{3} \mathbf{b}$ produced the best SI values for T. cruzi INC-5, the most interesting compounds of the series are $\mathbf{3 a}$ and $\mathbf{3} \mathbf{c}$, since they were the only species showing trypanocidal activity in both strains with minimum cytotoxic effect. Thus, these compounds are the best candidates for further studies since they have similar or better selectivity than that of the reference drugs.

The bloodstream trypomastigotes of T. cruzi NINOA were more sensitive to both series of BTA and reference drugs, requiring lower concentrations to reach the $50 \%$ lysis of the parasites in comparison with those of the T. cruzi INC-5 string. This is probably due to the different origin of both strains because the T. cruzi NINOA strain was isolated form a patient with acute Chagas, while the T. cruzi INC-5 strain was obtained from a chronic Chagas patient. Besides, it is well known that among the T. cruzi strains, there is a wide genetic diversity, and thus their biological behavior may vary [22].

Interestingly, structure-activity relationship analysis (SAR) showed that the amount of fluorine in the BTA molecules plays an important role on their trypanocidal activity. Thus, compounds $\mathbf{3} \mathbf{d}$ and $\mathbf{3 e}$ did not show lytic activity on either of the strains, having only one fluorine on their structures, and their trypanocidal activity is low in comparison with that observed, in both strains, for compounds $3 f$ and $\mathbf{3 g}$, which have two or more fluorines on their structures. In addition, compound $3 \mathbf{b}$ has a single chlorine proved to be active with the T. cruzi INC-5 strain, however, not with T. cruzi NINOA strain.

On the other hand, compounds $\mathbf{3 a}$ and $\mathbf{3 c}$, which do not have halogens on their structures, only exhibited moderated trypanocidal activity. While derivatives $\mathbf{3 a}, \mathbf{3 b}$, and $\mathbf{3} \mathbf{c}$ were the less cytotoxic (Table 2). Noteworthy is the fact that cytotoxicity increases for those BTA's with fluorines on their structures, with a clear trend of increase in their cytotoxicity as the number of fluorines on their structures increases, i.e., $3 g=3 f>3 e>3 d$.

Improving selectivity in drug design is a must. Thus, from the series of BTA's compounds attained, it was important to determine whether their biological activity was a consequence of being selective or due to their general toxicity [23]. Thus, results from the experiments showed that in the case of compounds $3 \mathrm{f}$ and $\mathbf{3 g}$ their trypanocidal effect is due to toxicity and not to selectivity. Meanwhile, those compounds without halogens on their structures, i.e., 3a and 3c, exhibited the best SI indexes (Table 2) for both strains.

In summary, we synthesized, in a facile manner, a series 2-substituted-BTA's, that exhibited good trypanocidal activity at low concentrations, thus being promising candidates for further, more detailed studies in both in vitro and in vivo or to be used as a base for the further improved design of other similar molecules in the search for more efficient and more selective compounds (in silico studies). Some of these approaches, including the anti-inflammatory and antioxidant studies of the series of BTA compounds, are currently under development in our laboratories.

\section{Materials and Methods}

\subsection{Reagents and Apparatus}

All reagents used were commercially obtained from Sigma-Aldrich Chemical Co., Inc. (St Louis, $\mathrm{MO}$, USA), and were used as received without further purification. Solvents were supplied by J.T. Baker (Phillipsburg, NJ, USA), which were dried and distilled prior to use, using standard procedures established under dinitrogen atmosphere. The melting points were determined and are reported without correction using a MELT-TEMP II Laboratory Devices, and vibrational spectroscopy IR was 
performed in the range of 4000 to $350 \mathrm{~cm}^{-1}$ in a NICOLET MAGNA spectrometer $750 \mathrm{FT}-\mathrm{IR}$ in $\mathrm{KBr}$ discs. MS-ESI were carried out using a JEOL JMS-SX102A spectrometer. NMR spectra were recorded in DMSO- $d_{6}$ at room temperature on a JEOL spectrometer GX300 ECLIPSE with $300 \mathrm{~Hz}$ frequency for ${ }^{1} \mathrm{H}, 75 \mathrm{~Hz}$ for ${ }^{13} \mathrm{C}\left\{{ }^{1} \mathrm{H}\right\}, 282 \mathrm{~Hz}$ for ${ }^{19} \mathrm{~F}\left\{{ }^{1} \mathrm{H}\right\}$. The chemical shifts $(\delta)$ for ${ }^{1} \mathrm{H}$ and ${ }^{13} \mathrm{C}\left\{{ }^{1} \mathrm{H}\right\}$ are reported in ppm at low field in relation to TMS or the residual signal of the solvents employed. In the case of the ${ }^{19} \mathrm{~F}\left\{{ }^{1} \mathrm{H}\right\}, \mathrm{F}_{3} \mathrm{CCO}_{2} \mathrm{H}$ was used as external reference. All reactions were performed in open atmosphere.

\subsection{Synthesis of 2-benzylsulfanyl BTAs Derivatives (1-7)}

The BTA derivatives were obtained by the following general procedure: A suspension of 2-mercaptoBTA (1.0 eq) and $\mathrm{K}_{2} \mathrm{CO}_{3}(1.1 \mathrm{eq})$ in THF, where the corresponding benzyl chloride (1.1 eq) was added dropwise and, thereafter, a catalytic amount of KI was added. The reaction mixture was stirred at room temperature for $24 \mathrm{~h}$. The course of the reaction was monitored by thin-layer chromatography. Over time, the reaction mixture was filtered and washed with $\mathrm{CH}_{2} \mathrm{Cl}_{2}(3 \times 20 \mathrm{~mL})$. The organic filtrate was washed with brine $(20 \mathrm{~mL})$, dried with anhydrous $\mathrm{Na}_{2} \mathrm{SO}_{4}$, and evaporated in vacuo to give solids, in most of cases, which were purified by recrystallization from hexane: AcOEt 9:1 to afford amorphous solids.

2-(benzylthio)benzo[d]thiazole (3a). Light yellow amorphous solid (1.5 g, $5.8 \mathrm{mmol}, 75 \%)$, mp 34-36 ${ }^{\circ} \mathrm{C}$. IR (KBr), $v\left(\mathrm{~cm}^{-1}\right)$ : 3106, 3083, 3056, 3030, 2926, 2838, 1898, 1817, 1688, 1584, 1558, 1492, 1453, 1421, 1307, 1274, 1236, 1190, 1120, 1074, 994, 933, 916, 889, 858, 811, 768, 748, 706, 673, 620. MS-ESI, $m / z: 258$ $\left(100,\left[\mathrm{M}^{+}+1\right]\right) .{ }^{1} \mathrm{H}$ NMR $\left(300 \mathrm{MHz}, \mathrm{DMSO}-d_{6}\right), \delta(\mathrm{ppm}): 8.14(\mathrm{~d}, J=7.9 \mathrm{~Hz}, 1 \mathrm{H}, \mathrm{Ar}), 8.04(\mathrm{~d}, J=8.1 \mathrm{~Hz}$, $1 \mathrm{H}, \mathrm{Ar}), 7.50-7.45(\mathrm{~m}, 3 \mathrm{H}, \mathrm{Ar}), 7.37-7.32(\mathrm{~m}, 3 \mathrm{H}, \mathrm{Ar}), 7.29-7.26(\mathrm{~m}, 1 \mathrm{H}, \mathrm{Ar}), 4.80\left(\mathrm{~s}, 2 \mathrm{H}, \mathrm{CH}_{2}\right) .{ }^{13} \mathrm{C}\left\{{ }^{1} \mathrm{H}\right\}$ NMR (75 MHz, DMSO-d $\left.d_{6}\right), \delta$ (ppm): 166.03, 152.56, 136.47, 134.62, 128.99, 128.50, 127,52, 126.32, 124.44, 121.72, 121.13, 36.57. Elem. Anal. Anal. Calc. for $\mathrm{C}_{14} \mathrm{H}_{11} \mathrm{NS}_{2}\left(257.37 \mathrm{gmol}^{-1}\right)$ : C, 65.33; $\mathrm{H}, 4.31 ; \mathrm{N}, 5.44$; S, 24.92 Found: C 64.83, H 4.29, N, 5.40; S 24.46.

2-(4-chlorobenzylthio)benzo[d]thiazole (3b). Yellowish amorphous solid (1.2 g, $4.11 \mathrm{mmol}, 80 \%)$, mp 78-80 ${ }^{\circ} \mathrm{C}$. IR (KBr), v $\left(\mathrm{cm}^{-1}\right)$ : 3060, 2923, 1589, 1555, 1487, 1453, 1421, 1307, 1273, 1235, 1187, 1120, 1088, 997, 939, 892, 862, 828, 805, 751, 726, 701, 679, 645. MS-ESI m/z: $292\left(100,\left[\mathrm{M}^{+}+1\right]\right), 294\left(45,\left[\mathrm{M}^{+}+\right.\right.$ 2]), 295 (10), 258 (20),125 (12). ${ }^{1} \mathrm{H}$ NMR (300 MHz, DMSO- $\left.d_{6}\right) \delta(\mathrm{ppm}): 7.84$ (d, $\left.J=8.0 \mathrm{~Hz}, 1 \mathrm{H}, \mathrm{Ar}\right)$, $7.75(\mathrm{~d}, J=8.1 \mathrm{~Hz}, 1 \mathrm{H}, \mathrm{Ar}), 7.38(\mathrm{~d}, J=6.8 \mathrm{~Hz}, 1 \mathrm{H}, \mathrm{Ar}), 7.33(\mathrm{t}, J=7.2 \mathrm{~Hz}, 1 \mathrm{H}, \mathrm{Ar}), 7.25-7.20(\mathrm{~m}, 3 \mathrm{H}$, Ar), $\left.4.63\left(\mathrm{~s}, 2 \mathrm{H}, \mathrm{CH}_{2}\right) .{ }^{13} \mathrm{C}^{1}{ }^{1} \mathrm{H}\right\} \mathrm{NMR}\left(75 \mathrm{MHz}, \mathrm{DMSO}-d_{6}\right), \delta$ (ppm): 165.77, 152.52, 136.86, 134.69, $132.17,131.91,128.46,126.38,124.54,122.79,121.22,36.71$. Elem. Anal. Anal. Calc. for $\mathrm{C}_{14} \mathrm{H}_{10} \mathrm{Cl}_{1} \mathrm{~N}_{1} \mathrm{~S}_{2}$ (291.82 $\mathrm{gmol}^{-1}$ ): C, 57.62; H, 3.45; N, 4.80; S, 21.98 Found: C 57.80, H 3.42, N, 4.68; S 22.00.

2-(4-methoxybenzylthio)benzo[d]thiazole (3c). Yellow amorphous solid (1.17 g, $4.07 \mathrm{mmol}, 80 \%)$, mp 63-65 ${ }^{\circ} \mathrm{C}$. IR (KBr), $v\left(\mathrm{~cm}^{-1}\right)$ : 3050, 3009, 2949, 2930, 2903, 2832, 1985, 1878, 1724, 1610, 1581, 1507, 1456, 1424, 1301, 1279, 1235, 1197, 1174, 1124, 1093, 1071, 1025, 995, 935, 898, 823, 752, 698. MS-ESI $\mathrm{m} / z: 288\left(30,\left[\mathrm{M}^{+}+1\right]\right), 121(100) .{ }^{1} \mathrm{H}$ NMR $\left(300 \mathrm{MHz}, \mathrm{DMSO}-d_{6}\right) \delta(\mathrm{ppm}): 8.00(\mathrm{~d}, J=7.9 \mathrm{~Hz}, 1 \mathrm{H}, \mathrm{Ar})$, $7.89(\mathrm{~d}, J=8.1 \mathrm{~Hz}, 1 \mathrm{H}, \mathrm{Ar}), 7.50-7.33(\mathrm{~m}, 4 \mathrm{H}, \mathrm{Ar}), 6.9(\mathrm{~d}, J=8.6 \mathrm{~Hz}, 2 \mathrm{H}, \mathrm{Ar}), 4.72\left(\mathrm{~s}, 2 \mathrm{H}, \mathrm{CH}_{2}\right), 3.86$ $\left.\left(\mathrm{s}, 3 \mathrm{H}, \mathrm{OCH}_{3}\right) .{ }^{13} \mathrm{C}^{1}{ }^{1} \mathrm{H}\right\} \mathrm{NMR}\left(75 \mathrm{MHz}, \mathrm{DMSO}-d_{6}\right), \delta(\mathrm{ppm}): 166.22,158.72,152.62,134.62,130.33$, $128.11,126.34,124.45,121.75,121.14,113.95,55.04,36.36$. Elem. Anal. Anal. Calc. for $\mathrm{C}_{15} \mathrm{H}_{13} \mathrm{~N}_{1} \mathrm{O}_{1} \mathrm{~S}_{2}$ (287.4 gmol$\left.^{-1}\right)$ : C, 62.69; H, 4.56; N, 4.87; S, 22.31 Found: C 62.57, H 4.54, N, 4.74; S 22.13.

2-(4-fluorobenzylthio)benzo[d] thiazole (3d). Yellowish amorphous solid (1.47 g, $6.24 \mathrm{mmol}, 73 \%), \mathrm{mp}$ 61-63 ${ }^{\circ} \mathrm{C}$. IR (KBr), v $\left(\mathrm{cm}^{-1}\right)$ : 3429, 3064, 2928, 2850, 1735, 1596, 1503, 1453, 1422, 1370, 1308, 1270, 1243, $1219,1154,1122,1108,1077,1054,1016,990,940,899,832,751,725,704,690,668$. MS-EI $m / z: 275(38$, $\left.\left[\mathrm{M}^{+}+1\right]\right), 109$ (100), $242(20), 179$ (2), $166(5), 139$ (2), $122(3), 83$ (12), 69 (3), 63(3), 39(3). ${ }^{1} \mathrm{H} \mathrm{NMR}$ $\left(300 \mathrm{MHz}, \mathrm{DMSO}-d_{6}\right) \delta(\mathrm{ppm}): 8.10(\mathrm{~d}, J=7.9 \mathrm{~Hz}, 1 \mathrm{H}, \mathrm{Ar}), 8.0(\mathrm{~d}, J=8.1 \mathrm{~Hz}, 1 \mathrm{H}, \mathrm{Ar}), 7.68-7.63(\mathrm{~m}, \mathrm{Ar})$, $7.58(\mathrm{t}, \mathrm{Ar}), 7.47(\mathrm{t}, J=7.5 \mathrm{~Hz}, 1 \mathrm{H}, \mathrm{Ar}), 7.27(\mathrm{t}, J=8.7 \mathrm{~Hz}, 2 \mathrm{H}, \mathrm{Ar}), 4.75\left(\mathrm{~s}, 2 \mathrm{H}, \mathrm{CH}_{2}\right) .{ }^{13} \mathrm{C}\left\{{ }^{1} \mathrm{H}\right\} \mathrm{NMR}$ (75 MHz, DMSO- $\left.d_{6}\right), \delta(\mathrm{ppm}): 165.94,161.54(\mathrm{~d}, J=243.9 \mathrm{~Hz}), 152.58,134.70,132.92(\mathrm{~d}, J=3.1 \mathrm{~Hz}), 131.12$ $(\mathrm{d}, J=8.3 \mathrm{~Hz}), 126.40,124.54,121.80,121.20,115.36(\mathrm{~d}, J=29.5 \mathrm{~Hz}), 35.74 .{ }^{19} \mathrm{~F}\left\{{ }^{1} \mathrm{H}\right\} \mathrm{NMR}(282 \mathrm{MHz}$, 
DMSO- $\left.d_{6}\right) \delta$ (ppm): -114.58. Elem. Anal. Anal. Calc. for $\mathrm{C}_{14} \mathrm{H}_{10} \mathrm{~F}_{1} \mathrm{~N}_{1} \mathrm{~S}_{2}\left(275.36\right.$ gmol $\left.^{-1}\right)$ : C, 61.06; $\mathrm{H}$, 3.66; N, 5.09; S, 23.29 Found: C 61.02, H 3.58, N, 5.11; S 23.23.

2-(3-fluorobenzylthio)benzo[d]thiazole (3e). Amber liquid (1.25 g, $4.54 \mathrm{mmol}, 83 \%)$. IR (KBr), v $\left(\mathrm{cm}^{-1}\right)$ : 3060, 2931, 1738, 1614, 1587, 1486, 1453, 1424, 1307, 1256, 1236, 1135, 1074, 993, 942, 879, 784, 751, 723, 707, 678. MS-ESI $m / z$ : 276(100, [M $\left.\left.{ }^{+}+1\right]\right), 277$ (18), $278(10) .{ }^{1} \mathrm{H}$ NMR (300 MHz, DMSO- $\left.d_{6}\right) \delta(\mathrm{ppm}):$ $8.00(\mathrm{~d}, J=7.9 \mathrm{~Hz}, 1 \mathrm{H}, \mathrm{Ar}), 7.90(\mathrm{~d}, J=8.1 \mathrm{~Hz}, 1 \mathrm{H}, \mathrm{Ar}), 7.47(\mathrm{t}, J=7.6 \mathrm{~Hz}, 1 \mathrm{H}, \mathrm{Ar}), 7.36(\mathrm{t}, 4 \mathrm{H}, \mathrm{Ar}), 7.11$ $(\mathrm{t}, J=7.9 \mathrm{~Hz}, 1 \mathrm{H}, \mathrm{Ar}), 4.77\left(\mathrm{~s}, 2 \mathrm{H}, \mathrm{CH}_{2}\right) .{ }^{13} \mathrm{C}\left\{{ }^{1} \mathrm{H}\right\} \mathrm{NMR}\left(75 \mathrm{MHz}, \mathrm{DMSO}-d_{6}\right), \delta(\mathrm{ppm}): 165.79,162.02(\mathrm{~d}$, $J=243.9 \mathrm{~Hz}), 152.54,140.11(\mathrm{~d}, J=7.7 \mathrm{~Hz}), 134.73,130.95(\mathrm{~d}, J=8.5 \mathrm{~Hz}), 126.40,125.19,124.55,121.81$, 121.20, $116.30(\mathrm{~d}, J=21.9 \mathrm{~Hz}), 114.90(\mathrm{~d}, J=20.9 \mathrm{~Hz}), 33.59 .{ }^{19} \mathrm{~F}\left\{{ }^{1} \mathrm{H}\right\} \mathrm{NMR}\left(282 \mathrm{MHz}\right.$, DMSO- $\left.d_{6}\right) \delta$ (ppm): -112.97. Elem. Anal. Anal. Calc. for $\mathrm{C}_{14} \mathrm{H}_{10} \mathrm{~F}_{1} \mathrm{~N}_{1} \mathrm{~S}_{2}\left(275.36\right.$ gmol $\left.^{-1}\right)$ : C, 61.06; H, 3.66; N, 5.09; S, 23.29 Found: C 60.98, H 3.63, N, 5.01; S 23.15.

2-(2,6-difluorobenzylthio)benzo[d]thiazole (3f). Amber liquid (1.152 g, $3.93 \mathrm{mmol}, 77 \%)$. IR (KBr), $v\left(\mathrm{~cm}^{-1}\right)$ : 3376, 3062, 3000, 2953, 1738, 1623, 1589, 1561, 1509, 1465, 1424, 1375, 1308, 1272, 1236, 1164, 1131, 1074, 993, 936, 853, 826, 786, 753, 725, 702, 661. MS-ESI m/z: 294 (100, [M $\left.\left.{ }^{+}+1\right]\right), 295$ (42), 296 (25). ${ }^{1} \mathrm{H}$ NMR $\left(300 \mathrm{MHz}, \mathrm{DMSO}-d_{6}\right) \delta(\mathrm{ppm}): 8.14(\mathrm{~d}, J=7.8 \mathrm{~Hz}, 1 \mathrm{H}, \mathrm{Ar}), 8.02(\mathrm{~d}, J=8.0 \mathrm{~Hz}, 1 \mathrm{H}, \mathrm{Ar}), 7.63-7.48(\mathrm{~m}$, $3 \mathrm{H}, \mathrm{Ar}), 7.26(\mathrm{t}, J=8.0,2 \mathrm{H}, \mathrm{Ar}), 4.81\left(\mathrm{~s}, 2 \mathrm{H}, \mathrm{CH}_{2}\right) .{ }^{13} \mathrm{C}\left\{{ }^{1} \mathrm{H}\right\} \mathrm{NMR}\left(75 \mathrm{MHz}, \mathrm{DMSO}-d_{6}\right), \delta(\mathrm{ppm}): 164.73$, $160.62(\mathrm{dd}, J=249.8,8.8 \mathrm{~Hz}), 152.54,134.96,131.05(\mathrm{t}, J=10.4 \mathrm{~Hz}), 126.50,124.80,121.93,112.27(\mathrm{~m})$, 24.49. ${ }^{19} \mathrm{~F}\left\{{ }^{1} \mathrm{H}\right\}$ NMR $\left(282 \mathrm{MHz}, \mathrm{DMSO}-d_{6}\right) \delta$ (ppm): -113.36. Elem. Anal. Anal. Calc. for $\mathrm{C}_{14} \mathrm{H}_{9} \mathrm{~F}_{2} \mathrm{~N}_{1} \mathrm{~S}_{2}$ (293.35 $\left.\mathrm{gmol}^{-1}\right)$ : C, 57.32; H, 3.09; N, 4.97; S, 23.08 Found: C 57.13, H 3.02, N, 5.01; S 23.15.

2-(perfluorobenzylthio)benzo[d] thiazole (3g). Yellowish amorphous solid (1.298 g, $3.73 \mathrm{mmol}, 86 \%)$, mp $54-56{ }^{\circ} \mathrm{C}$. IR (KBr), $v\left(\mathrm{~cm}^{-1}\right)$ : 3065, 2963, 1737, 1654, 1501, 1454, 1423, 1306, 1274, 1237, 1169, 1123, 1078, $1038,985,967,882,756,726,703,682,640,603$. MS-ESI $m / z: 348\left(100,\left[\mathrm{M}^{+}+1\right]\right), 349(45), 350(25) .{ }^{1} \mathrm{H}$ NMR $\left(300 \mathrm{MHz}\right.$, DMSO- $\left.d_{6}\right) \delta(\mathrm{ppm}): 8.04(\mathrm{~d}, J=7.90 \mathrm{~Hz}, 1 \mathrm{H}, \mathrm{Ar}), 7.87(\mathrm{~d}, J=8.1 \mathrm{~Hz}, 1 \mathrm{H}, \mathrm{Ar}), 7.50(\mathrm{t}$, $J=7.60 \mathrm{~Hz}, 1 \mathrm{H}, \mathrm{Ar}), 7.40(\mathrm{t}, J=7.6,1 \mathrm{H}, \mathrm{Ar}), 4.77\left(\mathrm{~s}, 2 \mathrm{H}, \mathrm{CH}_{2}\right) .{ }^{13} \mathrm{C}\left\{{ }^{1} \mathrm{H}\right\} \mathrm{NMR}\left(75 \mathrm{MHz}, \mathrm{DMSO}-d_{6}\right), \delta$ (ppm):164.01, 152.37, $144.84(\mathrm{dt}, J=244.2,13.5 \mathrm{~Hz}), 140.15(\mathrm{dt}, J=248.8,13.5 \mathrm{~Hz}), 136.90(\mathrm{dt}, J=249.9$, $15.8 \mathrm{~Hz}), 135.01,126.53,124.88,122.00,121.35,111.36(\mathrm{t}, J=19.5 \mathrm{~Hz}), 24.21 .{ }^{19} \mathrm{~F}\left\{{ }^{1} \mathrm{H}\right\} \mathrm{NMR}(282 \mathrm{MHz}$, DMSO- $\left.d_{6}\right) \delta(\mathrm{ppm}):-140.92(\mathrm{dd}, J=22.8,7.2 \mathrm{~Hz}),-154.91,-155.11(\mathrm{~m}),-162.54-162.71(\mathrm{~m})$. Elem. Anal. Anal. Calc. for $\mathrm{C}_{14} \mathrm{H}_{6} \mathrm{~F}_{5} \mathrm{~N}_{1} \mathrm{~S}_{2}\left(347.33\right.$ gmol $\left.^{-1}\right)$ : C, $48.41 ; \mathrm{H}, 1.74 ; \mathrm{N}, 4.03 ; \mathrm{S}, 18.46$ Found: $\mathrm{C} 48.37$ $\mathrm{H} 1.67, \mathrm{~N}, 4.05 ; \mathrm{S} 18.50$.

\subsection{Biological Activity}

\subsubsection{Trypanocidal Activity Evaluation}

Compounds and reference drugs, nifurtimox (Nfx: Lampit ${ }^{\mathrm{TM}}$, Bayer) and Bnz (Rochagan ${ }^{\mathrm{TM}}$, Roche), were dissolved at $10 \mathrm{mg} / \mathrm{mL}$ in dimethyl sulfoxide (DMSO, Sigma-Aldrich), and corresponding dilutions were carried out in phosphate-buffered saline (PBS).

Bloodstream trypomastigotes of two strain of $T$. cruzi were used: NINOA strain (MHOM/MX/1994/NINOA, isolated from a patient in acute phase in Oaxaca, Mexico) and INC-5 strain (MHOM/MX/1994/INC5, isolated from a patient in chronic phase in Guanajuato, Mexico). CD1 mice 6-8 weeks old were intraperitoneally infected; at the maximum peak of parasitaemia (4 weeks), infected blood was obtained by cardiac puncture using heparin as anticoagulant. Infected blood was adjusted to $1 \times 10^{6}$ parasites $/ \mathrm{mL}$ and seeded into 96-well microplates. Animal experiments were performed according to Norma Oficial Mexicana (NOM-062-Z00-1999) published on august 22, 2009 entitled Technical specifications for the production, care and use of laboratory animals. The compounds were evaluated at different concentrations obtained by serial dilutions starting from $100 \mu \mathrm{g} / \mathrm{mL}$. In each well, $90 \mu \mathrm{L}$ of infected blood and $10 \mu \mathrm{L}$ of the corresponding compound or reference drug were deposited. A positive control of lysis reference drugs were used, and DMSO $1 \%$ was used as the negative control. All assays were performed in triplicate. The microplate was incubated $24 \mathrm{~h}$ at $4{ }^{\circ} \mathrm{C}$. 
The quantification of bloodstream trypomastigotes was performed by the Brener-Pizzi method, $5 \mu \mathrm{L}$ of blood was deposited between a slide and a coverslip $(18 \times 18 \mathrm{~mm})$, and all bloodstream trypomastigotes present in 20 fields were quantified in an optical microscope at $40 \times$. The amount of trypomastigotes from each sample was compared to the negative control and the percentage of lysis was determined; finally, the lytic concentration of $50 \%$ parasites $\left(\mathrm{LC}_{50}\right)$ were calculated for each compound and converted to micromolar data [23].

\subsubsection{Cytotoxic Activity Evaluation and SI}

For this assay, murine macrophage cell line J774A.1 (TIB-61 ATCC) were used in RPMI 1640 medium (Gibco, Carlsbad, CA, USA), enriched with 10\% inactivated fetal bovine serum (FBS, Gibco Carlsbad, CA, USA), $1 \%$ penicillin-streptomycin (In vitro S.A., Mexico City, Mexico) and 1\% MEM-NEA medium (Gibco, Carlsbad, CA, USA), the cells were kept at $37^{\circ} \mathrm{C}$ with $5 \% \mathrm{CO}_{2}$ and moisture atmosphere. Initially, on a 96-well microplate, they were placed $5 \times 10^{4}$ per well and incubated for $24 \mathrm{~h}$. The compounds were tested at different concentrations, starting from $100 \mu \mathrm{g} / \mathrm{mL}$ and by triplicate, as cytotoxicity negative control untreated cells were used. The microplate was incubated for $20 \mathrm{~h}$ under the same conditions; afterward, $10 \mu \mathrm{L}$ of resazurin (Invitrogen, Grand Island, NY, USA) $0.01 \%$ was added and incubated for an additional $4 \mathrm{~h}$ period. The microplate was analyzed on a fluorometer at $544 \mathrm{~nm}$ excitation/590 nm emission (Spectramax Plus; Molecular Devices, Sunnyvale, CA, U.S.). As a negative control of cytotoxicity, macrophages treated with $0.1 \%$ DMSO were used. The cytotoxic concentration of $50 \%$ of population $\left(\mathrm{CC}_{50}\right)$ was determined using the de Probit statistical tool and converted to micromolar data. Finally, the ratio between $\mathrm{CC}_{50}$ of macrophages and $\mathrm{LC}_{50}$ of the bloodstream trypomastigotes $\left(\mathrm{CC}_{50} / \mathrm{CL}_{50}\right)$ was calculated to get $\mathrm{SI}$ values [23].

Author Contributions: A.A.-S. and D.M.-M. conceived and designed the experiments; A.A.-S., J.D.T.-A., F.D.-C., and M.E.V.-D. performed the chemical and spectroscopic experiments; B.N.-T. and K.F.C.-V. performed the biological experiments. All authors discussed the results and commented on the manuscript.

Funding: This research was funded by CONACYT 62267, SIP-IPN (grants 20170697, 2018500) and PAPIIT (grants No. IN207317).

Acknowledgments: A.A.-S. would like to acknowledge CONACYT 62267, SIP-IPN (grants 20170697, 2018500). We would like to thank Luis Velasco Ibarra, Dr. Francisco Javier Pérez Flores, Q. Eréndira García Ríos, Lucia del Carmen Márquez Alonso, Lucero Ríos Ruiz, Alejandra Núñez Pineda (CCIQS), Q. María de la Paz Orta Pérez, and Q. Roció Patiño-Maya for technical assistance. PAPIIT (grants No. IN207317) is gratefully acknowledged.

Conflicts of Interest: The authors declare no conflict of interest.

\section{References}

1. Mariappan, G.; Prabhat, P.; Sutharson, L.; Banerjee, J.; Patangia, U.; Nath, S. Synthesis and antidiabetic evaluation of benzothiazole derivatives. J. Korean Chem. Soc. 2012, 56, 251-256. [CrossRef]

2. Malik, S.; Bahare, R.S.; Khan, S.A. Design, synthesis and anticonvulsant evaluation of N-(benzo[d]thiazol-2ylcarbamoyl)-2-methyl-4-oxoquinazoline-3(4H)-carbothioamide derivatives: A hybrid pharmacophore approach. Eur. J. Med. Chem. 2013, 67, 1-13. [CrossRef] [PubMed]

3. Noolvi, N.M.; Patel, H.M.; Kaur, M. Benzothiazoles: Search for anticancer agents. Eur. J. Med. Chem. 2012, 54, 447-462. [CrossRef] [PubMed]

4. Tariq, S.; Kamboj, P.; Alam, O.; Amir, M. 1,2,4-Triazole-based benzothiazole/benzoxazole derivatives: Design, synthesis, p38 $\alpha$ MAP kinase inhibition, anti-inflammatory activity and molecular docking studies. Bioorg. Chem. 2018, 81, 630-641. [CrossRef] [PubMed]

5. Burger, A.; Sawhey, S.N. Antimalarials. III. Benzothiazole amino alcohols. J. Med. Chem. 1968, 11, $270-273$. [CrossRef] [PubMed]

6. Dar, A.A.; Shadab, M.; Khan, S.; Ali, N.; Khan, A.T. One-pot synthesis and evaluation of antileishmanial activities of functionalized S-Alkyl/Aryl benzothiazole-2-carbothioate scaffold. J. Org. Chem. 2016, 81, 3149-3160. [CrossRef] [PubMed] 
7. Gabriel Navarrete-Vázquez, G.; Chávez-Silva, F.; Colín-Lozano, B.; Estrada-Soto, S.; Hidalgo-Figueroa, S.; Guerrero-Álvarez, J.; Méndez, S.T.; Reyes-Vivas, H.; Oria-Hernández, J.; Canul-Canché, J.; et al. Synthesis of nitro(benzo)thiazole acetamides and in vitro antiprotozoal effect against amitochondriate parasites Giardia intestinalis and Trichomonas vaginalis. Bioorg. Med. Chem. 2015, 23, 2204-2210. [CrossRef]

8. Ge, J.F.; Zhang, Q.Q.; Lu, J.M.; Kaiser, M.; Wittlin, S.; Brunb, R.; Ihara, M. Synthesis of cyanine dyes and investigation of their in vitro antiprotozoal activities. Med. Chem. Commun. 2012, 3, 1435-1442. [CrossRef]

9. Pudhom, K.; Kasai, K.; Terauchi, H.; Inoue, H.; Kaiser, M.; Brun, R.; Iharaa, M.; Takasu, K. Synthesis of three classes of rhodacyanine dyes and evaluation of their in vitro and in vivo antimalarial activity. Bioorg. Med. Chem. 2006, 14, 8550-8563. [CrossRef]

10. Hout, S.; Azas, N.; Darque, A.; Robin, M.; Di Giorgio, C.; Gasquet, M.; Galy, J.; Timon-David, P. Activity of benzothiazoles and chemical derivatives on Plasmodium falciparum. Parasitology 2004, 129, 525-542. [CrossRef]

11. Ferraza, L.R.M.; Alvesa, A.É.G.; Nascimentoa, D.D.S.S.; Amarizb, I.A.E.; Ferreira, A.S.; Costa, S.P.M.; Rolimb, L.A.A.; Limac, Á.A.N.; Rolim Neto, P.J. In vitro activity of steroidal dendrimers on Trypanosoma cruzi epimastigote form with PAMAM dendrons modified by "click" chemistry. Acta Trop. 2018, 185, 127-132. [CrossRef]

12. World and Health Organization. Neglected Tropical Diseases. Available online: https://www.who.int/en/ news-room/fact-sheets/detail/chagas-disease-(american-rypanosomiasis) (accessed on 1 February 2019).

13. Papadopoulou, M.V.; Bloomer, W.D.; Rosenzweig, H.S.; Kaiser, M.; Eric Chatelain, E.; Ioset, J.-R. Novel 3-nitro-1H-1,2,4-triazole-based piperazines and 2-amino-1,3-benzothiazoles as antichagasic agents. Bioorg. Med. Chem. 2013, 21, 6600-6607. [CrossRef]

14. Schmunis, G.A.; Yadon, Z.E. Chagas disease: A Latin American health problem becoming a world health problem. Acta Trop. 2010, 115, 14-21. [CrossRef] [PubMed]

15. Díaz-Chiguer, D.L.; Márquez-Navarroa, A.; Nogueda-Torres, B.; León-Ávila, G.L.; Pérez-Villanueva, J.; Hernández-Campos, A.; Castillo, R.; Ambrosio, J.R.; Nieto-Menesesa, R.; Yépez-Mulia, L.; et al. In vitro and in vivo trypanocidal activity of some benzimidazole derivatives against two strains of Trypanosoma cruzi. Acta Trop. 2012, 122, 108-112. [CrossRef] [PubMed]

16. Bern, C.N. Chagas' Disease. Engl. J. Med. 2015, 373, 456-466. [CrossRef] [PubMed]

17. Ballari, M.S.; Cano, N.H.; Lopez, A.G.; Wunderlin, D.A.; Feresín, G.E.; Santiago, A.N. Green synthesis of potential antifungal agents: 2-benzyl substituted thiobenzoazoles. J. Agric. Food Chem. 2017, 65, 10325-10331. [CrossRef]

18. Shi, L.; Liu, X.; Zhang, H.; Jiang, Y.; Ma, D. Synthesis of 2-thio-substituted benzothiazoles via a domino condensation/S-arylation/heterocyclization process. J. Org. Chem. 2011, 76, 4200-4204. [CrossRef]

19. Chu, X.-Q.; Jiang, R.; Fang, Y.; Gu, Z.-Y.; Meng, H.; Wang, S.-Y.; Ji, S.-J. Acidic-functionalized ionic liquid as an efficient, green, and metal-free catalyst for benzylation of sulfur, nitrogen, and carbon nucleophiles to benzylic alcohols. Tetrahedron 2013, 69, 1166-1174. [CrossRef]

20. Klimesova, V.; Koci, J.; Palat, K.; Stolarikova, J.; Dahse, H.-M.; Mollmann, U. Structure-activity relationships of 2-benzylsulfanylbenzothiazoles: Synthesis and selective antimycobacterial properties. Med. Chem. 2012, 8, 281-291. [CrossRef]

21. Brenière, S.F.; Waleckx, E.; Barnabé, C. Over Six thousand Trypanosoma cruzi strains classified into Discrete Typing Units (DTUs): Attempt at an inventory. PLoS Negl. Trop. Dis. 2016, 10, e0004792.

22. Dos-Santos, V.A.F.F.; Leite, K.M.; da Costa-Siqueira, M.; Regasini, L.O.; Martinez, I.; Nogueira, C.T.; Kolos Galuppo, M.; Stolf, B.S.; Soares-Pereira, A.M.; Cicarelli, R.M.B.; et al. Antiprotozoal activity of quinonemethide triterpenes from Maytenus ilicifolia (Celastraceae). Molecules 2013, 18, 1053-1062. [CrossRef]

23. Chacón-Vargas, K.F.; Nogueda-Torres, B.; Sánchez-Torres, L.E.; Suarez-Contreras, E.; Villalobos-Rocha, J.C.; Torres-Martinez, Y.; Lara-Ramirez, E.E.; Fiorani, G.; Krauth-Siegel, R.L.; Bolognesi, M.L.; et al. Trypanocidal activity of quinoxaline 1,4 di- $\mathrm{N}$-oxide derivatives as trypanothione reductase inhibitors. Molecules 2017, 22, 220-238. [CrossRef]

Sample Availability: Samples of the compounds are not available from the authors.

(C) 2019 by the authors. Licensee MDPI, Basel, Switzerland. This article is an open access article distributed under the terms and conditions of the Creative Commons Attribution (CC BY) license (http://creativecommons.org/licenses/by/4.0/). 